conventional impact tests. Most of the comments on Dr. Hoff's paper dealt with fundamental ideas, although such practical matters as the value of impact tests were raised. There was general agreement with Dr. Hoff that it is not possible to apply metal tests to such heterogeneous materials as plastics. The mechanism of breaking was discussed, since it is not clear how molecules can become disentangled if viscous flow does not exist below the transition point. Dr. Hoff agreed there is evidence that carbon-carbon linkages are probably broken, although a mechanism involving the separation of bundles of molecules may also occur. Other topics brought up included : the production of a 'standard' scratch, the effect of plasticizer on stress/time curves, the 'memory' of test pieces after deformation (particularly in connexion with intermittent loading), and the 'weakest link' type of fracture. Finally, stress was laid on the importance of distribution curves in test work, and the necessity for keeping molecular mechanisms in mind when statistical analyses are being made.

"Two Extrusion Plastometers for use with Polyvinyl Chloride" was the subject of a paper by R. Hayes. Arising from the importance of 'flow' properties, he explained that two types of plastometer have been developed. The first consists essentially of a heated metal block containing a chamber from which plastic is forced by a known pressure through a weight-loaded lever. The time taken for extrusion of a standard volume of material is determined at various pressures, flow-time/pressure curves are drawn, and the pressure required to extrude material at a standard rate is taken as the index of flow. The second instrument is essentially a modification of the Atkinson and Nancarrow plastometer. The extrusion piston is driven down at constant speed, and develops a pressure which is recorded through a pressure capsule. Both instruments are empirical in character and were designed for development and factory control work.

In the final paper, on "Indentation Testing of Phenolic Mouldings by Brinell and Hot Needle Methods", by J. H. Bennitt and C. E. Avenell, Mr. Bennitt explained that the object was to explore the possibility of using indentation tests, which could be made quickly and accurately with minimum damage, as a means of checking properties of mouldings. The Brinell (cold ball) test has been found useful in determining compositions of mouldings and gross differences in curing. Chemical resistance can also be followed; for example, there is a direct relationship between absorption of sulphuric acid and change in depth of indentation. The hot-needle machine, originally developed by Bisterfeld and Stolting in Germany, gives similar correlations. Thus, depth of penetration is directly connected with degree of cure, resistance to chemicals and types of filler. Mr. Bennitt doubted whether the test is suitable for routine testing of degree of cure, but he gave various examples of its utility, for example, in showing that discoloration in mouldings had been caused by hot spots during moulding, and in following the rate of curing of silicone mouldings. This paper brought questions on the relation between indentation of mouldings and degree of water penetration, the influence of specimen thickness and the application of the hot-needle test to acid-resisting cements and to post-stoved mouldings.

Dr. D. J. van Wijk, of the Netherlands Plastics Research Institute of Delft, made an important contribution to the ensuing discussion. He criticized normal test methods on three scores: they bear little relation to the characteristic properties of plastics; time or speed of deformation are entirely neglected; and results of destructive tests are influenced by many unknown factors. The tests fail to provide a better understanding of the real elastic, visco-elastic and plastic properties because results cannot be expressed as ultimate physical constants. As examples, he pointed out that $E$ (modulus of elasticity) is not a constant but depends on temperature and time, and ageing-characteristics affect the results. $\mathrm{He}$ also mentioned the significant importance of relaxation times, and finally asked that more attention should be paid to creep and high-frequency vibration phenomena.

N. J. L. MegsoN

\section{CHEMICAL ENGINEERING AT THE CROSS-ROADS}

TN his presidential address entitled "Chemical Engineering at the Cross-Roads", delivered at the thirtieth annual corporate meeting of the Institution of Chemical Engineers, Sir Harold Hartley described chemical engineering as the fourth primary technology. He said that, just as the older technologies of civil, mechanical and electrical engineering developed when specialized knowledge increased, so the chemical engineer has evolved as a separate entity owing to the immense advances in the chemical and allied industries during the present century. The chemical engineer does not compete with engineers of the older classes, but works in harmony with them and supplements their knowledge. All engineers make use of practical experience based on scientific principles to solve the many problems which confront them ; in the case of the chemical engineer, the directions in which he can apply his knowledge are so varied that it is becoming increasingly difficult to decide how he should be trained. It would seem, said Sir Harold, that even more emphasis than at present must be placed on the basic sciences and fundamental laws, so that a scientific rather than an empirical approach becomes natural, while flexibility of outlook and acquaintance with the methods of research are of vital importance. With such a background, technical details can be assimilated readily.

To illustrate the varied directions in which a chemical engineer may turn, Sir Harold quoted a few examples. One of the engineer's main tasks is the efficient use of energy; a modern steam power station depends largely upon the correct application of chemical engineering principles, while oil refining, with its most recent development the synthesis of chemicals, is a fast-expanding industry requiring chemical engineers by the hundred. Even more important will be the work of the chemical engineer when the 'fossil fuels' upon which we so largely depend for heat and power approach exhaustion. He is already attempting to produce atomic energy economically; to-morrow his task may be to utilize solar energy for controlled photosynthesis. In another direction he must devise means for extracting metals from ores of ever-diminishing richness, and in yet another he must endeavour to make increasing use of the so-called waste which arises during the pro- 
cessing of natural materials. In agriculture the production of improved fertilizers, weed-killers, fungicides and insecticides, as well as antibiotics to eliminate disease in man and animals, is still in its infancy, and a vast new field awaits the large-scale application of biochemistry.

Amid so many possibilities, continued Sir Harold, only one thing seems certain-there are not nearly enough chemical engineers for the task, especially in Great Britain : for every chemical engineer now training in Britain there are more than twenty in the United States. It would be of some help if chemical engineering were included in the curriculum of every institution now teaching engineering of the older kind, but urgent action is required. If British industry is to maintain the lead won for it by its engineers in the past, a great and rapid increase in the number of chemical engineers must be regarded as one of the major needs of to-day.

\section{TECHNOLOGY AND THE HISTORY OF MAN}

TN his L. T. Hobhouse Memorial Trust Lecture at 1 the London School of Economics and Political Science on October 23, 1951 (Pp. 19. London : Oxford University Press, 1952. 2s. net), Dr. Charles Singer, dealing with technology and history, said that it was largely through Hobhouse's influence that the view that the history of mankind should be considered as a whole and include all major human activities is now a commonplace among the English-speaking peoples. Nevertheless, Dr. Singer continued, despite the limitations of the idea of history that prevailed in the nineteenth century, efforts to integrate the records of the various manifestations of the human spirit can be traced back at least to L. Laurent's "'tudes sur l'Histoire de l'Humanité", which began to appear in 1855 , to J. R. Green's "History of the English People" in the late seventies, and to H. D. Traill's "Social England", the last volume of which appeared in 1897. The United Nations Educational, Scientific and Cultural Organization is now engaged on the preparation of an integrated "Scientific and Cultural History of Mankind", some part of which might be expected about 1958.

One of the difficulties in this task, Dr. Singer pointed out, is that the time-curves of the rise and fall of the different forms of human activity do not always fit each other ; and, for the history of technology in particular, the ordinary year-sequences cannot yield a useful framework. Division on a cultural basis appears to be more promising, and Dr. Singer suggested that for the history of technology the most convenient divisions are those made as follows: first, between the fishing and hunting stage (roughly, the Old Stone Age) and the agricultural stage (roughly, the New Stone Age); secondly, between the latter and the great social change which Prof. V. Gordon Childe has named the "Urban Revolution"; thirdly, between the latter and the discovery of gold and copper and the invention of writing; and fourthly, from this to the decline of the ancient empires about 500 B.C.

For the following period, until A.D. 1500, there is at present, said Dr. Singer, neither the knowledge nor the scholar to write an adequate history of Far Eastern technology, and in its place we can only substitute an account of the technology of the civil- izations of the Mediterranean and the Near East and their medieval successors. The rise of experimental science in the period 1450-1650 gave the fifth great dividing line, and from the latter date self-conscious science began to determine the main direction of technology. There is no comprehensive survey of the history of technology, though for the mid-eighteenth century Diderot and his collaborators in the "Encyclopædia of the Sciences, Arts and Crafts" have provided more detailed and complete information than we have for any other. Dr. Singer concluded with a brief reference to the industry and contributions of C. Frémont and Dr. Henry Dickinson.

\section{BRITISH HYDROMECHANICS RESEARCH ASSOCIATION REPORT FOR 1951}

$A \mathrm{~T}$ the annual general meeting of the British Hydromechanics Research Association, Viscount Waverley was re-elected president, and a council of eighteen elected with Dr. A. Ivanoff (Hayward-Tyler and Co., Ltd.) as chairman and Mr. H. N. G. Allen (W. H. Allen, Sons and Co., Ltd.) deputy chairman. Mr. G. A. Wauchope (Gwynne Pumps, Ltd.), the retiring chairman, was elected the first vice-president of the Association.

In the fourth annual report of the council, covering the period October 1950-September 1951*, reference is made to the completion of the Association's 14,000 sq. ft. laboratory and to the official opening, on May 24, 1951, by the president. The laboratory was the first industrial building to be erected in the new satellite town of Harlow, Essex. It consists of a large, mainly single-story, building. Sufficient experimental equipment has been installed and workshop facilities provided to enable the Association's staff to commence active research, in addition to maintaining the information and abstracting services to members of the Association. The two-story office block which adjoins the laboratory includes a library, drawing office, dark room and instrument laboratory.

The membership of the Association continues to increase, though somewhat slowly. A list of the ordinary and associate members is given in the annual report. It comprises forty manufacturing and user members, and forty-nine consultants and academic workers. The majority of the eligible companies in the pump industry are now members of the Association, but it is regrettable that, as yet, no financial support has been forthcoming from water-supply authorities, though they are among the principal users of much of the plant and machinery with which the Association is concerned. A grant is received from the Department of Scientific and Industrial Research, and close contact is maintained with the Fluid Mechanics Division of the Mechanical Engineering Research Organization at East Kilbride, Glasgow, and with university and independent research workers in hydraulics. The staff consists of the director of research, Mr. L. E. Prosser, a secretary, five research engineers, two research assistants and one draughtsman, in addition to library, office and workshop staff. It has been strengthened during the year under review by the recruitment of several junior staff.

* British Hydromechanics Research Association. Fourth Annual Report, October 1950 to September 1951. Pp. 28. (Harlow, Essex the Association, 1951.) 